FRANÇAIS À LA PAGE SUIVANTE

\title{
Twenty-five years of AIDS
}

A IDS simmered for years in Africa before it was recognized in the United States in I98I as an epidemic among homosexual men. Its origin is no longer a mystery. Thanks to the high science of gene sequencing and phylogenetic analysis, we can pinpoint the monkey troupe from which HIV-I originated in West Africa. How the virus might have begun as a zoonosis from its natural home in chimpanzees is an open question, but the pandemic is credibly attributed to high population, crowding, wars, migration, poverty, commercial sex, other sexually transmitted infections, travel, illicit and medical injection drug use and even the practice (or not) of male circumcision in the context of sexual transmission. After a quarter century, AIDS is just another grim fact of life, added to the shopping list of infectious diseases that kill millions every year.

In Western countries, medical and scientific milestones in HIV/AIDS have been regularly achieved. By 1985 , the virus was isolated and named by competing scientific rivals in France and the United States. The US Centers for Disease Control and Prevention showed epidemiologic proof that HIV causes AIDS. The blood transfusion supply became protected through donor screening and blood testing, although not quickly enough for all those who had need - despite the technical capability, logistical incapacity and economic limitations in several countries left many people infected with HIV from blood transfusions in the mid-I98os, later to die of AIDS. The courts have decided that the delay was wrong, and the legal consequences are still unfolding.

Other milestones in Western countries include antimicrobial drug treatment for the prevention of opportunistic infections. Developed by trial and error, preventive therapy improved the health and lives of people with AIDS years before effective specific anti-HIV drug treatment became available. By I995 to 2000, a succession of new anti-HIV drugs was developed, which, when used in combination, led to dramatic decreases in AIDS-related mortality in countries where the drugs were marketed, and health care \& was provided.

However, despite these medical and scientific marvels in the Western world, in the poorest and hardest-hit countries, the annual number of AIDS-related deaths has passed the millions, and the ambitious 5-year goal of the World Health Organization and UNAIDS to provide antiretroviral treatment to 3 million (less than 1 year's global incidence of HIV infec- tion) by the end of 2005 fell short by about 2 million. ${ }^{1}$ Despite the technical and medical possibilities, the logistical, economic and brutal political realities have prevented HIV treatment from reaching $95 \%$ of the people who need it.

As a consequence of AIDS in the poorest and hardest-hit countries, prior steady improvement in life expectancy has been suddenly reversed by a combination of HIV infection and tuberculosis. The greater the mortality among young adults, the more millions of children are left without parents. The individual and social costs will be unmatched in deaths and disruption by wars, or by any other epidemics in living memory. Tens of millions of orphans in the poorest of countries is the prospect, and their fate will be another legacy of AIDS.

After 25 years of AIDS, we have the medical ability to treat HIV infection effectively, but not the logistical capacity or will to provide treatment or much of any medical health care where it is needed most. This may be as unjust as it was for the people infected with HIV through blood transfusions when the technical means to protect them were present, but there are no courts to decide. Political commitments and high science may deliver us the elusive HIV vaccine before we meet the next practical milestone: to bring the current successes of medicine to the poorest people, and not only in the poorest countries, who need it most.

Along with the introduction and distribution of basic and HIV-specific medical health care, the challenge of caring for and nurturing millions of children orphaned by AIDS will also be met with success or failure. May the next 25 years bring as many practical successes as we have seen in scientific milestones in the first 25 years of AIDS.

\section{William Cameron \\ Professor of Medicine \\ University of Ottawa \\ Ottawa Hospital \\ Ottawa, Ont.}

Competing interests: None declared.

\section{REFERENCE}

I. Nemes MIB, Beaudoin J, Conway S, et al. Evaluation of WHO's contribution to "3 by 5": main report. Geneva: World Health Organization; 2006 Mar 30 . Available: www.who.int/hiv/topics/me/3 by5evaluationreport.pdf (accessed 2006 July 5). 